Scientia Agricola

http://dx.doi.org/10.1590/0103-9016-2015-0269

\title{
Swine manure digestate treatment using electrocoagulation
}

\author{
Rúbia Mores ${ }^{1}$, Airton Kunz ${ }^{2,4}$, Juliana Steffens ${ }^{1 *}$, Rogério Marcos Dallago ${ }^{1}$, Toni Luis Benazzi ${ }^{3}$, André Cestonaro do Amaral ${ }^{4}$
}

${ }^{1}$ URI Erechim - Dept. of Agricultural Sciences, Av. Sete de Setembro, 1621 - 99709-910 - Erechim, RS - Brazil.

2Embrapa Swine and Poultry, Rod. BR-153, km 110 -

89700-000 - Concórdia, SC - Brazil.

3Federal Institute of Rio Grande do Sul, R. Domingos Zanella, 104 - 99713-028 - Erechim, RS - Brazil.

4UNIOESTE - PGEAGRI/CCET - Dept. of Agricultural

Engineering, R. Universitária, 2069 - 85819-110 -

Cascavel, PR - Brazil.

${ }^{*}$ Corresponding author <julianasteffens@yahoo.com.br>

Edited by: Julio César Pascale Palhares

Received July 02, 2015

Accepted November 05, 2015
ABSTRACT: Anaerobic biodigestion is an appropriate alternative for the treatment of swine wastewater due to its biogas generation properties and the possibility of its application as a source of energy for heating or electricity. However, digestate can still contain high levels of turbidity, organic carbon and nutrients and must be correctly managed as a biofertilizer, or treated to avoid any impact on the environment. Considering this, electrocoagulation (EC) shows promise as a technology because of its ease of handling and high efficiency in effluent remediation. This study aimed to evaluate the performance of EC in a batch system in the treatment of swine wastewater digestate. The wastewater used in the treatment was sampled from a 10 $\mathrm{m}^{3}$ biodigestor effluent (digestate) located at Concórdia, Santa Catarina, Brazil. A batch-scale experiment was carried out to evaluate the following two variables: electrode distance (ED) and voltage applied (V). The removal efficiency levels (\%) for the best operational condition $(2 \mathrm{~cm}$, $5 \mathrm{~V}$ ) after 30 min were: $97 \%, 98 \%, 77 \%$ and $10 \%$ for color, turbidity, total organic carbon (TOC) and total nitrogen (TN), respectively. The EC batch system produced efficient results, underlining its promise as an alternative to be applied in the treatment of digestate. Keywords: electrode distance, voltage, factorial design, batch system

\section{Introduction}

Wastewater generated in swine production in Brazil has increased as a result of the expansion of confined animal feeding operations (Broetto et al., 2014). One of the widespread alternatives for the management and treatment of swine wastewater is anaerobic digestion. This biological process converts organic matter into methane (Kothari et al., 2014; Mari et al., 2014) and generates effluent (digestate) that can be used as a biofertilizer. However, when land application is not possible, due to problems with nutrient balance (high chemical oxygen demand (COD), total nitrogen (TN) and total phosphorus (TP) content), digestate treatment alternatives must be used (Amaral et al., 2014a; Amaral et al., 2014b; Park et al., 2010).

According to Cho et al. (2010), electrocoagulation (EC) is a modern method to be applied as an alternative to the treatment of swine farming wastewater. EC has its advantages when compared to conventional methods such as: basic equipment, ease of operation, less retention time, reduction or no addition of chemical products as well as fast sedimentation of electrogenerated floc (Gengec et al., 2012; Tezcan Ün et al., 2009).

The EC process involves the generation of coagulant "in situ" by dissolving electrically aluminum ions. The generation of metal ions takes place at the anode, and hydrogen gas is released from the cathode. The hydrogen gas also helps float the flocculated particles out of the water (Daneshvar et al., 2012). According to Chen (2004), the chemical reactions that occur at the anode and the cathode may be summarized as follows:

$$
\begin{aligned}
& \text { Anode: } \mathrm{Al}_{(\mathrm{s})} \rightarrow \mathrm{Al}^{3}{ }_{\text {(aq) }}+3 \mathrm{e}^{-} \\
& \text {Cathode: } 2 \mathrm{H}_{2} \mathrm{O}+2 \mathrm{e}^{-} \rightarrow \mathrm{H}_{2(\mathrm{~g})}+2 \mathrm{O}^{\mathrm{H}-}
\end{aligned}
$$

According to Kobya et al. (2014), the main parameters that control the generation and concentration of aluminum hydroxide coagulant in the EC system are the initial $\mathrm{pH}$, the electrode distance (ED) and the voltage applied. However, it is reported that the optimum $\mathrm{pH}$ range for the formation of aluminum hydroxide with the minimum of solubility is between 5.2 - 8.8 (Jiménez et al., 2012; Mollah et al., 2001).

This study aimed to evaluate the effect of EC operational conditions, applied voltage (V) and electrode distance (ED), the removal of color, turbidity, total organic carbon (TOC) and total nitrogen (TN) in swine manure digestate.

\section{Materials and Methods}

\section{Sampling}

The swine wastewater (digestate) (Table 1) used in this study was collected in a $10 \mathrm{~m}^{3}$ fiberglass upflow effluent biodigester (Amaral et al., 2014b), located at a swine manure treatment station in Concórdia, Santa Catarina, Brazil $\left(27^{\circ} 18^{\prime}\right.$ S, 51 ${ }^{\circ} 59^{\prime}$ O). Samples were collected in $5 \mathrm{~L}$ polyethylene gallon containers and frozen at $-10{ }^{\circ} \mathrm{C}$.

The batch EC reactor $(1.7 \mathrm{~L})$ consisted of two pairs of aluminum electrodes $(130 \mathrm{~mm}$ height and 70 mm width), connected to a direct current power supply. Digestate $\mathrm{pH}$ had been previously adjusted to 6.0 using $\mathrm{HCl}$. The system was kept under constant stirring for 30 min. Samples of the experiments were collected at the following times: 0, 10, 20 and $30 \mathrm{~min}$ and submitted for analysis.

\section{Experimental Design}

To understand the effects of independent variables, the electrode distance (ED) and the applied voltage (V), 
a factorial design $2^{2}$ had been elaborated designed for 7 experiments $(4$ at different combinations and 3 central points). The real and coded variables values are described in Table 2.

\section{Analytical Methods}

The performance of the EC process was evaluated in terms of the following responses: color, turbidity, total organic carbon (TOC) and total nitrogen (TN). Turbidity was measured by the spectrophotometer method using the colorimeter; TOC was analyzed using Shimadzu (TOC-5000a) equipment (APHA, 2012). TN was analyzed also using Shimadzu (TOC-5000a) equipment; the sample was injected in an oven at 720 ${ }^{\circ} \mathrm{C}$ with atmospheric oxidant and catalyzed by platinum microspheres, where the TN in the sample thermally decomposes to create nitrogen monoxide. The chemiluminescence detector utilizes the gas-phase chemiluminescence of ozone and nitrogen monoxide, such that the detected nitrogen monoxide analog signal forms a peak. The $\mathrm{pH}$ was measured using a $\mathrm{pH}$ meter.

\section{Results and Discussion}

Figure 1 shows the removal efficiency of color (A), turbidity (B), TOC (C) and TN (D) obtained at different $\mathrm{ED}$ and $\mathrm{V}$, according to the EC operational period.

Color and turbidity reached $98 \%$ removal efficiency after $20 \mathrm{~min}$ of treatment, and TOC reached a removal stability level of $68 \%$ after 30 min of treatment (Figure 1). Consequently, the operating time of $30 \mathrm{~min}$ is considered optimum for achieving stability in the removal processes, especially in relation to color, turbidity and TOC.

Table 3 shows the factorial design $2^{2}$ matrix with its respective real and coded values and the responses in removal percentage after a $30 \mathrm{~min}$ treatment.

Table 1 - Digestate characterization collected in the fiberglass upflow biodigester used for electrocoagulation studies.

\begin{tabular}{lc}
\hline Parameter & \\
\hline Turbidity (UNT) & $4760.0 \pm 1165.3$ \\
Color $\left(\mathrm{mg}_{\text {PtCo }^{-1}}\right)$ & $30250.0 \pm 8273.7$ \\
TOC (mg L & $1937.2 \pm 607.3$ \\
TN (mg L & $1349.8 \pm 83.6$ \\
Conductivity (uS) & $8469.1 \pm 0.6$
\end{tabular}

Total Organic Carbon (TOC); Total Nitrogen (TN).

Table 2 - Original and coded variables in the factorial design for electrocoagulation experiments using digestate from swine effluent, anaerobically treated.

\begin{tabular}{lccc}
\hline Variables & \multicolumn{3}{c}{ Coded variables levels } \\
\hline Electrode distance & -1 & 0 & 1 \\
(cm) & 1 & 2 & 3 \\
Applied voltage (V) & 4 & 5 & 6 \\
\hline
\end{tabular}

The results presented in Table 3 show that runs employing ED of $1 \mathrm{~cm}$ and voltage of $4 \mathrm{~V}$ and $6 \mathrm{~V}$ (runs 1 and 3) had not presented removal efficiency for any of the evaluated responses. Conductivity of $8469.1 \mu \mathrm{S}$ combined with ED of $1 \mathrm{~cm}$ and the voltages of 4 and $6 \mathrm{~V}$ applied in the anode and cathode cause short circuits in the EC system. Consequently, under these conditions (runs 1 and 3) no remotions were observed. Mameri et al. (1998) studied the influence of ED on the removal of defluorination and verified that an ED of $0.5 \mathrm{~cm}$ combined with conductivity of 40 to $80 \mu \mathrm{S}$ and current density of $3.12 \mathrm{~m}^{-2}$ caused a short circuit in the EC system.

An increase from $1 \mathrm{~cm}$ to 2 and $3 \mathrm{~cm}$ in ED, favored removal for runs $2,4,5,6$ and 7 , with removal levels above $93 \%$ for color, $98 \%$ for turbidity and $68 \%$ for TOC. This is due to electrostatic effects dependent on the ED. Thus, when ED increases, ion displacement occurs allowing for the aggregation and formation of flocs, which, in turn, increase removal efficiency (Daneshvar et al., 2004; Nanseu-Njiki et al., 2009).

The efficiency in the removal of $\mathrm{TN}$ was lower than $11 \%$, removal stability being reached after $10 \mathrm{~min}$ of EC. Akyol et al. (2013) and Liu et al. (2015) observed the same behavior for $\mathrm{TN}$, with removal efficiencies of $18 \%$ and $6 \%$, respectively.

According to Mahvi et al. (2011), the EC does not remove TN (ammonia), and out of the electrochemical processes, electrooxidation is the mechanism responsible for ammonia removal in the effluent. Whereas ammonia is the form of nitrogen present in the digestate (Mezzari et al., 2013), a modification in the EC reactor configuration is required to increase the removal efficiency of TN (ammonia) by electrochemical process. Mahvi et al. (2011) proposed that electrodes of $\mathrm{Al}, \mathrm{RuO}_{2} / \mathrm{Ti}$ and stainless steel need to be inserted in an EC reactor, to form a configuration of electrocoagulation/electro-oxidation.

Recently, the anaerobic oxidation process (anaerobic ammonium oxidation - Anammox) has attracted attention because of its advantages compared to conventional nitrification-denitrification processes (Casagrande et al., 2013; Du et al., 2015). During the anammox process, ammonia nitrogen is converted into gaseous nitrogen. Because of its low C:N ratios the anammox process

Table 3 - Factorial design $2^{2}$ matrix with coded values (real) and responses for color, turbidity, total organic total (TOC) and total nitrogen (TN) for 30 min treatment and values of final $\mathrm{pH}$.

\begin{tabular}{cccccccccc}
\hline \multirow{2}{*}{ Run } & \multicolumn{2}{c}{ Variables of the process } & & \multicolumn{4}{c}{ Responses Removal (\%) } \\
\cline { 2 - 6 } \cline { 6 - 9 } & ED (cm) & Voltage (V) & & Color & Turbidity & TOC & TN & pH final \\
\hline 1 & $-1(1)$ & $-1(4)$ & & 0 & 0 & 0 & 0 & 6.8 \\
2 & $1(3)$ & $-1(4)$ & & 93 & 99 & 72 & 5 & 7.6 \\
3 & $-1(1)$ & $1(6)$ & & 0 & 0 & 0 & 6.4 \\
4 & $1(3)$ & $1(6)$ & & 97 & 99 & 68 & 3 & 8.1 \\
5 & $0(2)$ & $0(5)$ & & 97 & 98 & 78 & 10 & 8.1 \\
6 & $0(2)$ & $0(5)$ & & 97 & 98 & 78 & 11 & 8.1 \\
7 & $0(2)$ & $0(5)$ & 98 & 99 & 76 & 9 & 8.5 \\
\hline
\end{tabular}

$\mathrm{ED}=$ electrode distance. 
A

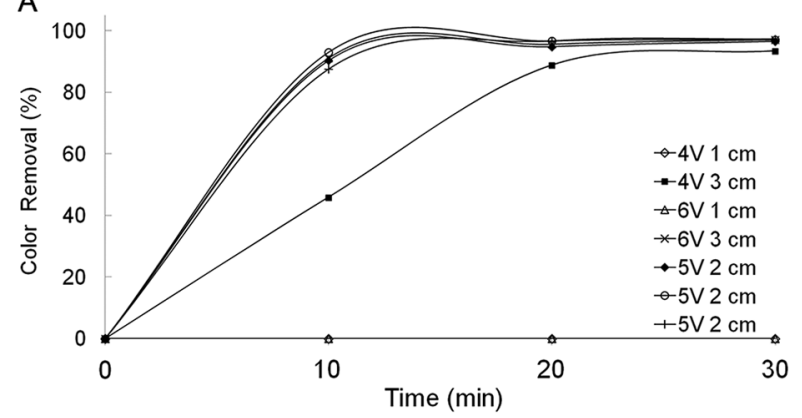

C

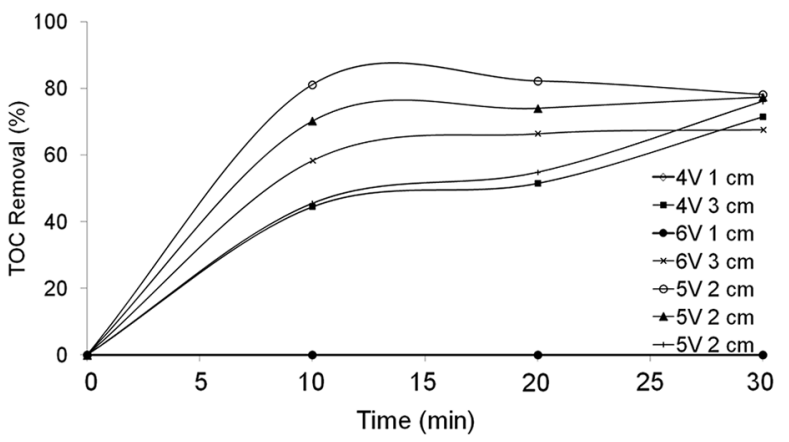

B

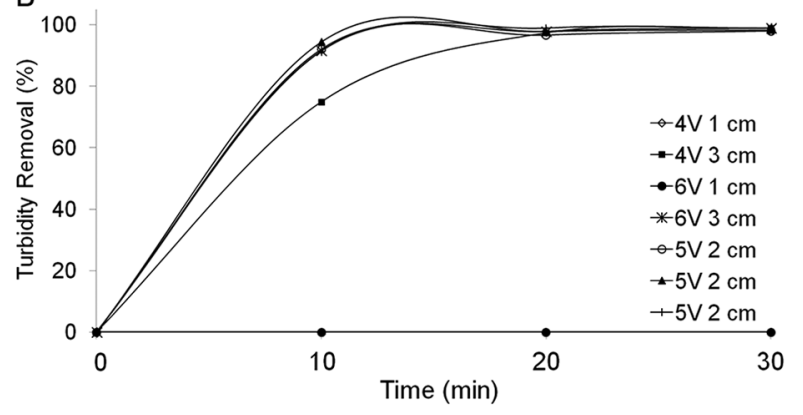

D 100

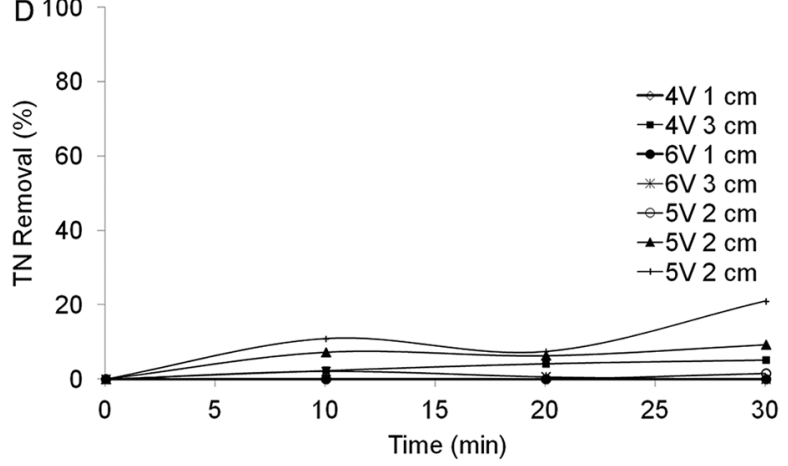

Figure 1 - Digestate submitted to electrocoagulation color (A), turbidity (B), total organic (TOC) (C) and total nitrogen (TN) (D) removal efficiency.

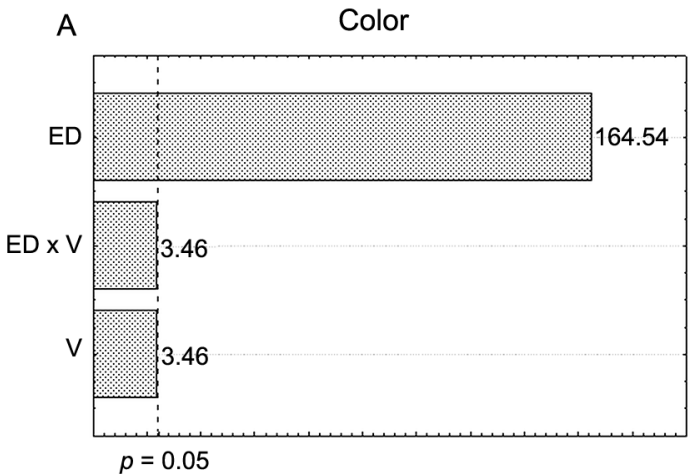

Standardized effect estimate (Absolute value)

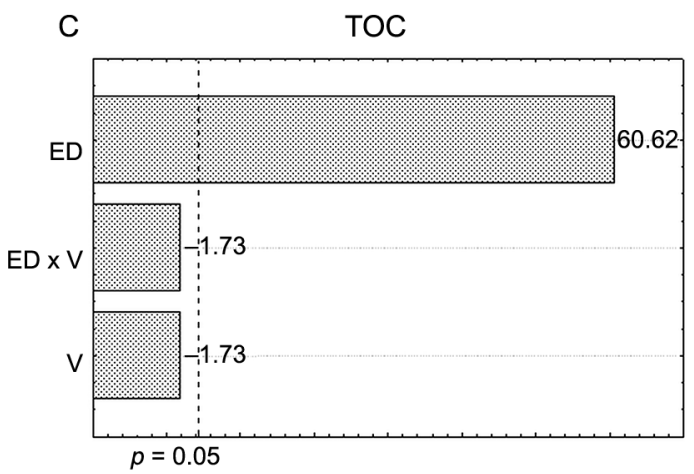

Standardized effect estimate (Absolute value)

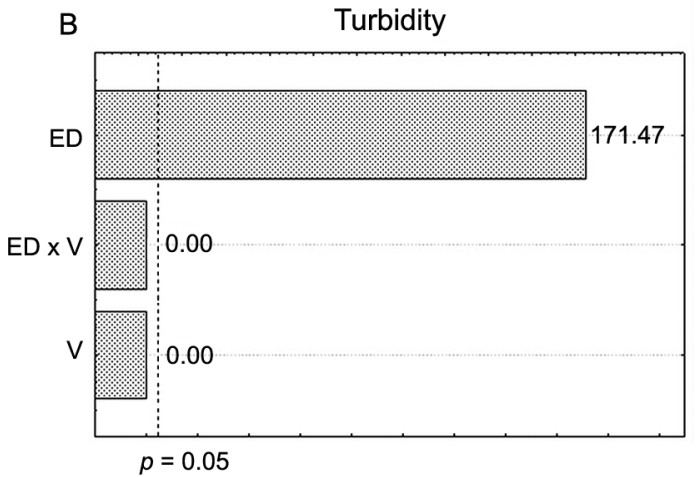

Standardized effect estimate (Absolute value)

D TN

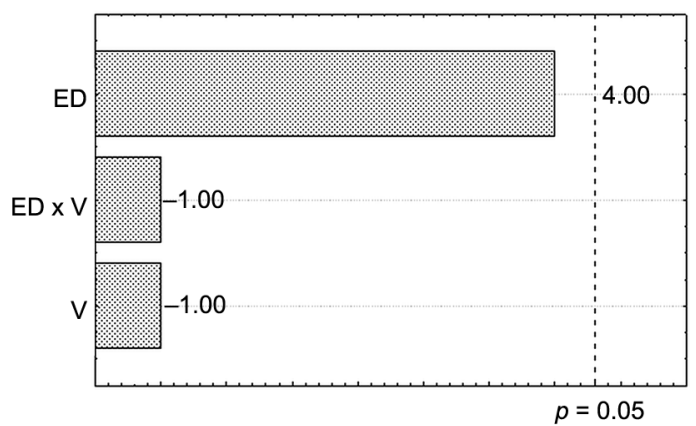

Standardized effect estimate (Absolute value)

Figure 2 - Pareto diagrams showing the importance of the effects of electrode distance (ED) and applied voltage (V) on removal percentage of responses color (A), turbidity (B) total organic carbon (TOC) (C) total nitrogen (TN) and (D). 
is suitable for wastewater. At $\mathrm{C}: \mathrm{N}$ ratios above 1 , the anammox bacteria cannot compete with heterotrophic denitrifying bacteria (Molinuevo et al., 2009). In this sense, the effluent from EC can provide adequate and stable conditions for Anammox.

As regards final $\mathrm{pH}$ (Table 3), independent of the variables of the processes (ED and voltage), there was an increase to between 6.4 and 8.5. The EC has the property of increasing the wastewater's $\mathrm{pH}$ after its treatment, due to $\mathrm{OH}^{-}$production in the cathode (Eq. 02) (Tezcan Ün and Ozel, 2013).

To better evaluate the influence of ED and the tension (V) applied to the EC process, an estimates analysis of independent variable effects over the dependent ones are presented in the Pareto diagrams (Figure 2A (color), B (turbidity), C (TOC) and D(TN)).

The results achieved demonstrate that the independent variable ED presented significant positive effects $(p<0.05)$ in terms of dependent variables on color, turbidity and TOC. The dependent variable TN did not present any significant effect on the independent variables ED and V.

Recent studies show increases in the ED results and a decrease in removal efficiency due to the fall in ohmic tension between the cathode and the anode (Anand et al., 2014; Attour et al., 2014; Merzouk et al., 2010; Zhang et al., 2013). However, in our study an inverse effect was observed, where an increase in $1 \mathrm{~cm}$ ED of 2 and $3 \mathrm{~cm}$ favored the removal of color, turbidity and TOC. This difference is due to the electrical conductivity of digestate $(8469.1 \mu \mathrm{S})$, because the electrical conductivity significantly affects the removal efficiency of the pollutants (Al-Shannag et al., 2015). It is inversely proportional to the ED (Akbal and Camci, 2011) and determines the effect of the mobility of ions in relation to the applied electric field (Vasudevan et al., 2013). Thus, it is recommended to use 2 and $3 \mathrm{~cm}$ of ED for the treatment of digestate using EC.

\section{Conclusion}

For the digestate treatment, the following two parameters were evaluated by electrocoagulation: distance between the electrodes and the voltage applied. The electrode distance was the variable that presented an effect on the treatment process. The increase in electrode distance from $1 \mathrm{~cm}$ to 2 and $3 \mathrm{~cm}$, favored removal of color, turbidity and total organic carbon with values above $93 \%, 98 \%$ and $68 \%$, respectively, and an operating time of $30 \mathrm{~min}$. The removal of total nitrogen was below $11 \%$, because the electrocoagulation did not promote ammonia oxidation in the digestate. Thus, the effluent from EC can provide adequate and stable conditions for Anammox.

Electrocoagulation batch technology offers as an alternative stage to be incorporated into the wastewater treatment system in swine farming due to its elevated efficiency levels on the removal of color, turbidity and TOC.

\section{Acknowledgements}

URI - Erechim, CAPES, CNPq, Embrapa Swine and Poultry and Eletrosul.

\section{References}

Akbal, F.; Camci, S. 2011. Copper, chromium and nickel removal from metal plating wastewater by electrocoagulation. Desalination 269: 214-222.

Akyol, A.; Can, O.T.; Demirbas, E.; Kobya, M. 2013. A comparative study of electrocoagulation and electro-Fenton for treatment of wastewater from liquid organic fertilizer plant. Separation and Purification Technology 112: 11-19.

Al-Shannag, M.; Al-Qodah, Z.; Bani-Melhem, K.; Qtaishat, M.R.; Alkasrawi, 2015. M. Heavy metal ions removal from metal plating wastewater using electrocoagulation: kinetic study and process performance. Chemical Engineering Journal 260: 749756.

Amaral, A.C.; Kunz, A.; Steinmetz, R.; Cantelli, F.; Scussiato, L.A.; Justi, K.C. 2014a. Swine effluent treatment using anaerobic digestion at different loading rates. Agricultural Engineering 34: 567-576.

Amaral, A.C.; Kunz, A.; Steinmetz, R.L.; Justi, K.C. 2014b. Zinc and copper distribution in swine wastewater treated by anaerobic digestion. Journal of Environmental Management 141: 132-137.

American Public Health Association [APHA]. 2012. Standard Methods for the Examination of Water and Wastewater. 21ed. APHA, Washington, DC, USA.

Anand, M.V.; Srivastava, V.C.; Singh, S.; Bhatnagar, R.; Mall, I.D. 2014. Electrochemical treatment of alkali decrement wastewater containing terephthalic acid using iron electrodes. Journal of the Taiwan Institute of Chemical Engineers 45: 908913.

Attour, A.; Touati, M.; Tlili, M.; Ben Amor, M.; Lapicque, F.; Leclerc, J.P. 2014. Influence of operating parameters on phosphate removal from water by electrocoagulation using aluminum electrodes. Separation and Purification Technology 123: 124-129.

Broetto, T.; Tornquist, C.G.; Bayer, C.; Campos, B.C.; Merten, C.G.; Wottrich, B. 2014. Soils and surface waters as affected by long-term swine slurry application in Oxisols of southern Brazil. Pedosphere 24: 585-594.

Casagrande, C.G.; Kunz, A.; De Prá, M.C.; Bressan, C.R.; Soares, H.M. 2013. High nitrogen removal rate using anammox process at short hydraulic retention time. Water Science and Technology 67: 968-975.

Chen, G. 2004. Electrochemical technologies in wastewater treatment. Separation and Purification Technology 38: 11-41.

Cho, J.H.; Lee, J.E.; Ra, C.S. 2010. Effects of electric voltage and sodium chloride level on electrolysis of swine wastewater. Journal of Hazardous Materials 180: 535-541.

Jiménez, C.; Sáez, C.; Martínez, F.; Cañizares, P.; Rodrigo, M.A. 2012. Electrochemical dosing of iron and aluminum in continuous processes: a key step to explain electro-coagulation processes. Separation and Purification Technology 98: 102108. 
Daneshvar, N.; Ashassi-Sorkhabi, H.; Kasiri, M.B. 2004. Decolorization of dye solution containing acid red 14 by electrocoagulation with a comparative investigation of different electrode connections. Journal of Hazardous Materials B112: 55-62.

Daneshvar, N.; Oladegaragoze, A.; Djafarzadeh, N. 2012. Decolorization of basic dye solutions by electrocoagulation: an investigation of the effect of operational parameters. Journal of Hazardous Materials 129: 116-122.

Du, R.; Peng, Y.; Cao, S.; Wang, S.; Wu, C. 2015. Advanced nitrogen removal from wastewater by combining anammox with partial denitrification. Bioresource Technology 179: 497504.

Gengec, E.; Kobya, M.; Demirbas, E.; Akyol, A.; Oktor, K. 2012. Optimization of baker's yeast wastewater using response surface methodology by electrocoagulation. Desalination 286: 200-209.

Kobya, M.; Gengec, E.; Sensoy, M.T.; Demirbas, E. 2014. Treatment of textile dyeing wastewater by electrocoagulation using $\mathrm{Fe}$ and $\mathrm{Al}$ electrodes: optimization of operating parameters using central composite design. Coloration Technology 130: 226-235.

Kothari, R.; Pandey, A.K.; Kuma, S.; Tyagi, V.V.; Tyagi, S.K. 2014. Different aspects of dry anaerobic digestion for bio-energy: an overview. Renewable and Sustainable Energy 39: 174-195.

Liu, Z.; Stromberg, D.; Liu, X.; Liao, W.; Liu, Y. 2015. A new multiple-stage electrocoagulation process on anaerobic digestion effluent to simultaneously reclaim water and clean up biogas. Journal of Hazardous Materials 285: 483-490.

Mameri, N.; Yeddou, A.R.; Lounici, H.; Belhocine, D.; Grib H.; Bariou, B. 1998. Defluoridation of septentrional Sahara water of north Africa by electrocoagulation process using bipolar aluminium electrodes. Water Research 32: 1604-1612.

Mahvi, A.H.; Ebrahimi, S.J.A.; Mesdaghinia, A.; Gharibi, H.; Sowlat, M.H. 2011. Performance evaluation of a continuous bipolar electrocoagulation/electrooxidation-electroflotation (ECEO-EF) reactor designed for simultaneous removal of ammonia and phosphate from wastewater effluent. Journal of Hazardous Materials 192: 1267-1274.

Mari, A.; Secco, D.; Kunz, A.; Edwiges, T.; Maro Junior, A.; Frigo, E.; Alves, H. 2014. Performance of up-flow anaerobic digester in solids removal and biogas production. International Journal of Food Agriculture and Environment 12: 1135-1139.
Merzouk, B.; Madani, K.; Sekki, A. 2010. Using electrocoagulationelectroflotation technology to treat synthetic solution and textile wastewater, two case studies. Desalination 250: 573-577.

Mezzari, M.P.; Silva, M.L.B.; Nicoloso, R.S.; Ibelli, A.M.G.; Bortoli, M.; Viancelli, A.; Soares, H.M. 2013. Assessment of $\mathrm{N}_{2} \mathrm{O}$ emission from a photobioreactor treating ammonia-rich swine wastewater digestate. Bioresource Technology 149: 327332.

Molinuevo, B.; García, M.C.; Karakashev, D.; Angelidaki, I. 2009. Anammox for ammonia removal from pig manure effluents: effect of organic matter content on process performance. Bioresource Technology 100: 2171-2175.

Mollah, M.Y.A.; Schennach, R.; Parga, J.P.; Cocke, D.L. 2001. Electrocoagulation (EC) science and applications. Journal of Hazardous Materials 84: 29-41.

Nanseu-Njiki, C.P.; Tchamango, S.R.; Ngom, P.C.; Darchen, A.; Ngameni, E. 2009. Mercury (II) removal from water by electrocoagulation using aluminum and iron electrodes. Journal of Hazardous Materials 168: 1430-1436.

Park, J.; Jin, H.F.; Lim, B.R.; Park, K.Y.; Lee, K. 2010. Ammonia removal from anaerobic digestion effluent of livestock waste using green alga Scenedesmus sp. Bioresource Technology 101: 8649-8657.

Tezcan Ün, Ü.; Koparal, A.S.; Öğütveren, Ü.B. 2009. Hybrid processes for the treatment of cattle-slaughterhouse wastewater using aluminum and iron electrodes. Journal of Hazardous Materials 164: 580-586.

Tezcan Ün, Ü.; Ozel, E. 2013. Electrocoagulation of yogurt industry wastewater and the production of ceramic pigments from the sludge. Separation and Purification Technology 120: 386-391.

Vasudevan, S.; Lakshmi, J.; Kamaraj, R.; Sozhan, G. 2013. A critical study on the removal of copper by an electrochemically assisted coagulation: equilibrium, kinetics, and thermodynamics. AsiaPacific Journal of Chemical Engineering 8: 162-171.

Zhang, S.; Zhang, J.; Wang, W.; Li, F.; Cheng, X. 2013. Removal of phosphate from landscape water using an electrocoagulation process powered directly by photovoltaic solar modules. Solar Energy Materials \& Solar Cells 117: 73-80. 